Journal of Balkumari College

ISSN 2467-9321 (Print), ISSN 2738 -957X (Online) Website: http://balkumaricollege.edu.np/journal

Volume : 10 Issue: 1 June 2021, Page No. 19-30

\title{
Effect of Credit Risk Management on Financial Performance Of Nepalese Commercial Banks
}

\author{
Dr. Guna Raj Chhetri \\ Lecturer, Balkumari College \\ grchhetri1@gmail.com
}

\begin{abstract}
The main purpose of this study is to investigate the effect of credit risk on the financial performance of commercial banks in Nepal. The panel data of seventeen commercial banks with 85 observations for the period of 2015 to 2020 have been analyzed. The regression model revealed that non - performing loan (NPLR) has negative and statistically significant impact on financial performance (ROA).Capital adequacy ratio (CAR) and bank size (BS) have negative and statistically no significant impact on financial performance (ROA). Credit to deposit (CDR) has positive but no significant relationship with the financial performance (ROA) and the study concluded that the management quality ratio $(\mathrm{MQR})$ has positive and significant relationship with the financial performance (ROA) of the commercial banks in Nepal. The study recommends that, it is fundamental for Nepalese commercial banks to practice scientific credit risk management, improve their efficacy in credit analysis and loan management to secure as much as possible their assets, and minimize the high incidence of non-performing loans and their negative effects on financial performance.
\end{abstract}

Keywords: Return on asset, capital adequacy ratio, non-performing loan ratio, management, and quality ratio, credit to deposit ratio and bank size.

\section{Introduction}

Banking sector is an important sector which supports economic development in any country. Financial institution plays an important role in accelerating development of the country. Bank failure is a problem in different countries. Risk may be defined as a probability or threat of damage, injury, liability, loss, or any other negative occurrence that is caused by external or internal vulnerabilities, and that may be avoided through preemptive action. Credit risks are not only argued to affect financial performance of loans but they also have far reaching implications. Similarly, credit risk is the king of all risks. Creditrisk is one of the most vital risks for banks. Credit risk arises from non-performance by a borrower. Itmay arise from either an inability or an unwillingness to perform in the pre-commitment contracted manner. The banks are inevitably exposed to credit risk because they grant credit facilities as they accept the deposits (Muriithi et al. 2016). Hence, business without any types of risks is not a business. Risk is inherent in banking business or any form of business. Banks and financial institutions are exposed to variety of risks among them credit risk is more severe than other risks.

Credit risk in banks may also arise due to internal weaknesses in any financial institutions such as management inefficiency. Management deficiency affects liquidity causing an increase in nonperforming loans. In addition, the non-performing loan (NPL) in the balance sheet of a financial institution represents the ratio of aggregate non-performing loans and the total grossloan. Banks performance with regards to credit risk depends on various internal and external factors. Internal factors are bank specific determinants and the external factors are the determinants related to economic environment. Proper credit management is a precondition for any financial institutions' stability and continuing profitability, albeitdeteriorating credit quality is the most frequent cause of poor financial performance of the financial institutions.

The health of the financial sector is a major concern of policy, especially in developing economies where failure in financial intermediation can disturb the economic growth and retards the developmentprocesses (Das \& Ghosh, 2013). Furthermore, it has been proved that the major economic upheavals are the result of banking crisis. The economic development and financial growth of a country is critically dependent on the financial performance and strength of its banking sector (Shukla,2015). The banking sectors serve as the backbone for the economic development of any country (Ahsan, 2016). The growth and financial stability of the country depends on the financial soundness of its banking sector. Sound financial health of the banks is the guarantee not only to their 
depositors but is equally significant for the shareholders, employees, and the economy as a whole (Mohiuddin, 2014).

Risk management issues in the banking sector do not only have greater impact on bank performancebut also on national economic growth and general business development. The bank's motivation forrisk management comes from those risks which can lead to underperformance. Credit risk management is indeed a very difficult and complex task in the financial industry because of the unpredictable nature of the macroeconomic factors coupled with the various microeconomic variables which are peculiar to the banking industry or specific to a particular bank. Credit risk refers to the risk that a borrower will default on any type of debt by failing to make required payments. The risk is primarily to the lender and includes lost principal and interest, disruption to cashflows, and increased collection costs. The loss may be complete or partial and can arise in a number of circumstances (Muriithi, 2016). Similarly, financial performance of commercial banks is the measureof the level commercial banks profit or loses within a specified time period. Various measures havebeen used to measure the financial performance of commercial banks.

Credit risk management is one of the most essential functions of the bank in the modern banking system. The risk is inherent in all aspect of banking business operations. Credit business is a one of themajor parts of the bank (Kattel, 2016).

Credit risk plays a crucial role on the bank's profitability as the large portion of the bank's revenue accrues from loans and advances from which interests is earned (Bhattarai, 2016). For this purpose, the Nepalese commercial banks will be chosen for the research study to examine the financial performanceof those selected banks by using CAMEL approach. This is an industry with a long history, giving thepossibility to look at changes over the past decades. There are plenty of actors in the industry which gives us the opportunity to investigate the industry dynamics.

\section{Statement of the Problem}

Banks use the deposits to generate credit for their borrowers, which is the main revenue generating activity for most banks. With the increase of credit transactions and loan customers in the nation's economy, credit expansion is inevitable. The trend in the sector shows growing bank deposit-loan ratio as the economy grows and so does credit risk. Credit risk impact on banking system is being failure to properly management of balance sheet which not only contributes to decline in net profit but also enhance liquidity crisis and has negatively effect on goodwill of thebank as well. Customer's level of confidence will be decline with the existing situationof financial performance of banks in future. They might be willing to withdraw their interest towards banking industry. The impact of credit risk on financial performance has been a topic of interest to many scholars since credit risk has been identified as one of the major factors known to impact the financial performance of banks. The overall objective of the study is to investigate the impact of credit risk on the financial performance of seventeen commercial banks. This study tries to answer the main question i.e.

- What is the effect of credit risk on the profitability of selected bank?

- Is there any relationship between profitability and credit risk?

\section{Objectives of the Study}

The main objective of this study is to examine the impact of credit risk on the financial performance of Nepalese Commercial Banks. The specific objectives are

- To study the effect of credit risk on the profitability of the selected commercial bank.

- To examine the relationship among profitability and credit risk, (capital adequacy, credit to deposit, management quality and bank size)

\section{Significance of the Study}

The result of this research will have implications and importance:

- To regulator and policymakers, the research will provide the basis for the regulatory policy framework to mitigate the financial system from the financial crisis and to better appreciate and quantify those credit risks exposures. 
- To investors, this study will help them to understand the factors that influence the returns on their investments.

- To commercial banks, this study will provide an insight into the credit risk attributes whichmay need to be incorporated in their investment decision processes. The study will improve not only researcher's scope of understanding risk management but also entire public hence gain exposure to the banking industry. These findings will be used as reference material by future researchers interested in further research on credit risk management and its effects on financial performance of Nepalese commercial banks.

\section{Limitations of the Study}

Due to various constraints and unfavorable situations during the entire research period, there has been following limitations in the study:

- This study is based on secondary data and covers the 5 years period i.e. 2015 to 2020 .

- Seventeen commercial banks of Nepal has been taken as a sample so that the research might not generalized all commercial banks.

- The research was conducted by taking major six variables i.e ROA, NPLR, CAR. CDR, MQR and BS of the bank which may not provide satisfactory result because it has not considered other variables that affects the financial performance of the commercial banks.

- Primary data is not in used in this research so that the qualitative aspects cannot be explores from this study.

\section{Literature Review}

Commercial banks is not influenced by the amount of credit and nonperforming loans suggesting that other variables other than credit and non-performing loans impact on profits. Commercial banks that are keen on making high profits shouldconcentrate on other factors other than focusing more on amount of credit and nonperforming loans.

Kurawa and Garba (2014) have assessed the effect of credit risk management (CRM) on the profitability of Nigerian banks with a view to discovering the extent to which default rate (DR), cost per assets (CLA), and capital adequacy ratio (CAR) influence banks profitability (ROA). The secondary data from the annual reports and accounts of quoted banks during the period of 2002 to 2011 were used for analysis. The author concluded that credit risk management components have a significant positive effect on the profitability of Nigerian banks.

Abiola and Olausi (2014) have analyzed the impact of credit risk management on the commercial banksperformance in Nigeria. The panel regression model was employed for the estimation of the model. Inthis model, Return on Equity (ROE) and Return on Asset (ROA) were used as the performance indicators whereas Non-Performing Loans (NPL) and Capital Adequacy Ratio (CAR) as credit risk management indicators of the commercial banks. The findings have revealed that credit risk management has a significant impact on the performance of the banks in Nigeria. Furthermore, the results have shown that the sampled have poor credit risk management practices; hence the high levelsof the non-performing loans in their loans portfolios. Despite the high levels of the NPLs, their profit levels keep rising as an indication of the transfer of the loan losses to other customers in the form of large interest margins.

Ugoani (2015) has examined the relationship of poor credit risk management and bank failure in Nigeria using survey research design. The results from CHI- square statistics revealed that weak corporate governance accelerates bank failures and the credit risk management functions is to the greatest extent the most diverse and complex activity in the banking business. The author, at last, concludes that poor credit risk management influences bank failures.

Bhattarai (2016) has conducted research and examined the effect of credit risk on performance of Nepalese commercial banks. The results revealed that non-performing loan ratio has negativeeffect on profitability of the commercial banks while cost per loan assets has positive effect on profitability. In addition to credit risk indicators, bank size has positive effect on profitability. Capitaladequacy ratio and cash reserve are not considered as the influencing variables on profitability of the banks. The study has concluded that there is significant relationship between profitability and credit risk indicators of the selected commercial banks in Nepal. Nepalese commercial banks have poor creditrisk management and hence the banks need to follow prudent credit risk management and safeguardingthe assets of the banks and protect the interests of the stakeholders. 
Gadzo, Kportorgbi and Gatsi (2019) have assessed the effect of credit and operational risk on the financial performance of universal banks in the context of the structural equation model (SEM). The results showed that credit risk influences financial performance negatively contrary to the empirical study but in line with the information asymmetry tenant of the lemon theory. It was also found that operational risk influences the financial performance of the universal banks in Ghana negatively. Furthermore, the study indicated that bank specific variables measured by (asset quality, bank leverage, cost to income ratio and liquidity) significantly influence credit risk, operational risk aswell as the financial performance of the universal banks positively.

Researcher recommend that banks be encouraged to cut-down their lending rates in other to decrease credit risk and subsequently boost profitability. Regarding operational risk, banks should reduce leverage and have their portfolio more concentrated on liquid investment income so as to boost profitability.

\section{Theoretical Framework}

CAMELS is a widely used approach to analyze a bank. CAMELS has a six components which include Capital Adequacy, Asset quality, Management capabilities, Earnings sufficiency, Liquidity position, and Sensitivity to market risk.

Baral (2005) has examined that the financial health ofthe joint venture banks in the CAMEL framework and found the health of joint venture banks is betterthan that of the other commercial banks. In addition to this, the perusal of indicators of different components of CAMEL have indicated that the financial health of joint venture banks is not so strongto manage the possible large scale shocks to their balance sheet and their health is fair.

Fredrick (2012) has concluded that credit risk management by use of CAMEL indicators has a strongimpact on the financial performance of the commercial banks in Kenya. The study reveals that capitaladequacy, asset quality, management efficiency and liquidity have weak relationship while earnings have strong relationship with the financial performance of the banks. This study has concluded that CAMEL model can be used as a proxy for credit risk management of the commercial banks in Kenya. Poudel (2012) has shown that default rate, cost per loan assets and capital adequacy ratio have an inverse impact of the bank's financial performance whereas default rate is the most predictor of the bank's financial performance.

\section{Conceptual Framework}

Independent Variables

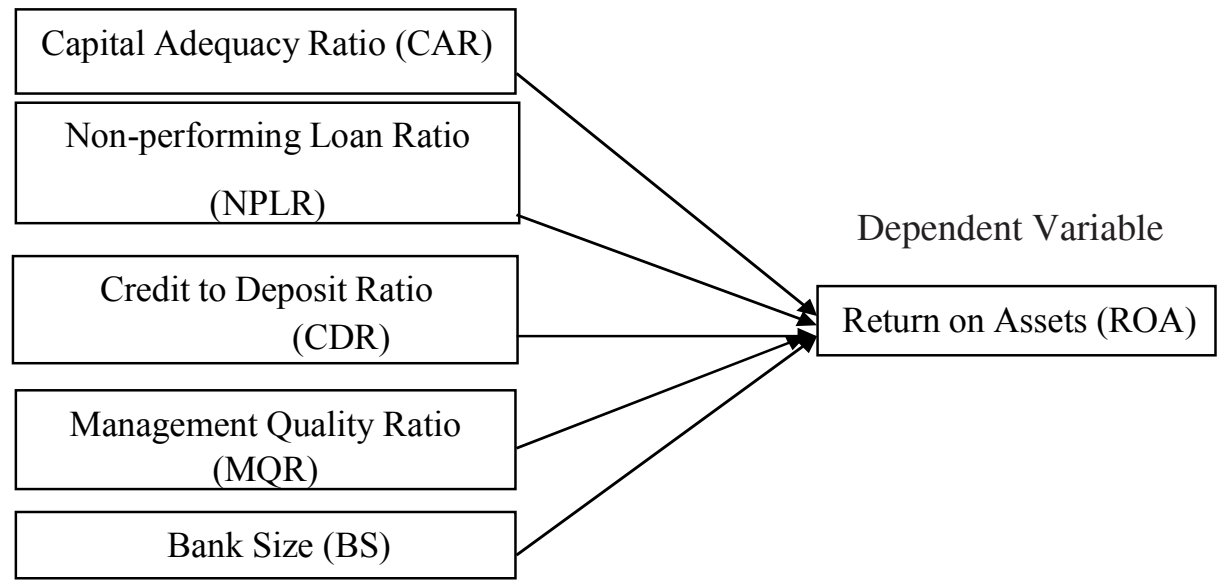

Fig.1. Conceptual Framework for the Study.

\section{Research Designs and Methods.}

This study examines the effect of credit risk on the performance of commercial banks in Nepal over the period of 5 years (2015-2020). The reason behind choosing of the latestsix year period is to include the afresh data in the analysis and as the data are from pooling of cross-sectional and time series, thus it seems sufficient to generate data for the analysis. This study has adopted descriptive and causal comparative research design. 
The convenience sampling method was used in choosing the banks for the study. Moreover, in selecting the 17 banks for the study, due care is given to include banks such as: joint venture, domestic, best performer, average performer and comparatively week performer in the sample. The banks selected for the study are: NMB Bank Ltd, Century Bank Ltd, Prime Commercial Bank Ltd, Standard Chartered Bank Ltd, Nepal Bangladesh Bank Ltd, Mega Bank Ltd, Kumari Bank Ltd, Siddhartha Bank Ltd, Nabil Bank Ltd, Civil Bank Ltd, NIC Asia Bank Ltd, Everest Bank Ltd., Citizen Bank International Ltd, Global IME Bank Ltd, Machhapuchchhre Bank Ltd., Nepal SBI Bank Ltd. And Agriculture Development Bank Ltd. The selected commercial banks appear fairly represent the study population. The population of this study constitutes the "A" class commercial banks in Nepal which are listed in the Nepalese Stock Exchange.

Data were sourced from the annual reports of the banks in the sample. The data include time-series and crosssectional data, i.e. pooled data set and estimated the effect of credit risk on the performance of commercial banks using pooled data regression. Data analysis was done using the Stata software.

\section{Study variable and hypothesis}

The dependent variables and independent variables used in this study are as follows:

Dependent variable. The measures of bank performance may be varied and the choice of the specific performance measure depends on the objective of the study. Thus, this study has used ROA as dependent variables to represent bank performance.

Return on Assets. (ROA)Return on Assets is the ratio of net income and total assets of any institutions. It measures the efficiency of the banks management in generating profits out of its scarce resources. The more the amount of ROA the better the efficiency of the bank management, (Gizaw, et al, 2015). Return on assets ratio is important profitability ratio because it measures the efficiency with which the company is managing its investment in asset and using them to generate profit (Harelimana, 2017).A basic measure of bank profitability that corrects the size of the bank is the return on assets ( $R O A)$, which divides the net income of the bank by the amount of its assets. $R O A$ is a useful measure of how well a bank manager is doing on the job because it indicates how well a bank's assets are being used to generate profits (Chowdhury, 2013). Furthermore, return on total assets measures the profitability of the total assets available to the business. It measures earnings in all investments provided by owners and creditors.

\section{Independent Variables.}

Capital adequacy ratio. This is an independent variable for the determination of the performance and is considered as the core measure of a bank's financial strength from a regulator's point of view.

Capital requirement (capital adequacy) is the amount of capital a bank or other financial institution has to hold as required by its financial regulator. It is a measure of the amount of bank's capital expressed as a percentage of its risk weighted exposure. It consists of the types of financial capital considered the mostreliable, primarily shareholders' equity. Theoretically, banks with good capital adequacy ratio have a good profitability. A bank with a strong capital adequacy is also able to absorb possible loan losses and thus avoids bank ,run, insolvency and failure.

Bank capital increases the capacity to raise non-insured debt and thus banks ability to limit the effect of a drop in deposits on lending. Since higher capital reduces bank risk and creates a buffer against losses, it makes funding with non-insured debt less information sensitive. Thus, capital adequacy can enhance bank performance. However, empirical studies on the relationship between firms performance and capital adequacy ratio have shown mixed results Jha and Hui (2012) have found negative association between capital adequacy ratio and ROA and the coefficient was statistically significant $(p<0.05)$. Ezike and Oke (2013) mentioned that holding capital beyond the optimal level would inversely affect the efficiency and profitability of commercial banks. 
$H_{1}$ : Capital adequacy ratio has a significant and positive effect on bank performance.

Asset Quality. The asset quality indicators highlight the use of non-performing loans ratios (NPLs) which are the proxy of asset quality, and the allowance or provision to loan losses reserve.Non-performing loans ratio (NPLR) reflects the bank's credit quality and is considered as an indicator of credit risk management. NPLR, in particular, indicates how banks manage their credit risk because it defines the proportion of loan losses amount in relation to total loan amount. NPLR has been used as the default rate on total loan and advances. However, empirical studies produce mixed results. Alshatti (2015) found the positive effect of non-performing/ gross loans ratio on the financial performance of banks. Contrary to these findings, Jha and Hui (2012) found negative association between NPL ratio and ROA but the coefficient is statistically insignificant. Although there are conflicting evidences on this issue, in view of the theoryand majority of the empirical literature, a negative relationship is expected between non- performing loan and bank"s performance $\left(\boldsymbol{\beta}_{2}<0\right)$.

\section{$H_{2}$ : Non-performing loan ratio has a significant and negative effect on bank performance.}

Liquidity. The credit to deposit ratio (CDR) is a major tool to examine the liquidity of a bank and measures the ratio of fund that a bank has utilized in credit out of the deposit total collected. Higher the CDR more the effectiveness of the bank to utilize the fund it collected (Jha \& Hui, 2012). This ratio measures theability of the management to use the assets in offering loans which ultimately creates high profitability(Ibrahim, 2014). This ratio helps us showing the relationship between loans and advances which are granted and the total deposited collected by the bank. A high ratio indicates better mobilization of collected deposit and vice-versa. It should be noted that too high ratio may not be better from liquiditypoint of view. This ratio is calculated dividing loan and advances by total deposits.

H3: Credit Deposit Ratio (CDR) has negative and significant related to bank performance.

Management Quality Ratio. Management soundness is a qualitative variable that expresses the control of board of directors over the resources of the bank to protect shareholders interest. It is measured by the ratio of total operatingincome to total assets.

H4: Total Operating income to Total Assets as a measure of Management Quality Ratio (MQR) has positive and significant related to bank performance.

Bank size. Bank size as measured by total assets is one of the control variables used in analyzing performance of the bank system (Smirlock, 1985). Bank size is generally used to capture potential economies or diseconomies of scale in the banking sector. This variable controlsfor cost differences in product and risk diversification according to the size of the financial institution. This is included to control for the possibility that large banks are likely to have greater product and loan diversification. In most finance literature, natural logarithm of total assets of the banks is used as a proxy for bank size. The effect of bank size on profitability is generally expected to be positive (Smirlock, 1985).

$H_{5}$ : Bank size has a significant and positive effect on bank performance.

\section{The model}

Pooled data regression model has been used in the analysis which was taken from (Bhattarai,2016) article.. The technique of pooled data estimation takes care of the problem of heterogeneity in the 17 banks selected for the study. The econometric model employed in the study is given as:

$Y=\beta_{0}+\beta X_{i t}+\varepsilon_{i t}$

Where: $Y$ is the dependent variable; $\beta_{0}$ is constant; $\beta$ is the coefficient of explanatory variables; $X_{i t}$ is the vector of explanatory variables; and $\varepsilon_{\text {it }}$ is the error term (assumed to have zero mean and independent across the time period). By adopting the prescribed econometric model, particularly to this study, the impact of credit risk (controlling the effect of cash reserve requirement and bank size) on the performance of the commercial banks has been estimated with the following regression equation:

$\mathrm{ROA}_{\mathrm{it}}=\beta_{0}+\beta_{1} \mathrm{CAR}_{\mathrm{it}}+\beta_{2} \mathrm{NPLR}_{\mathrm{it}}+\beta_{3} \mathrm{CDR}_{\mathrm{it}}+\beta_{5} \mathrm{BS}_{\mathrm{it}}+\mathrm{e}_{\mathrm{it}}$

Where: 
$\mathrm{ROA}_{\mathrm{it}}=$ Return on assets (ratio of earnings after taxes to total assets) of bank in year $\mathrm{t}$

$\mathrm{CAR}_{\mathrm{it}}=$ Capital adequacy ratio.

$\mathrm{NPLR}_{\mathrm{it}} \quad=$ Non-performing loan ratio of $\mathrm{i}$ year $\mathrm{t}$

$\mathrm{CDR}_{\mathrm{it}} \quad=$ Credit to deposit ratio of $\mathrm{i}^{\text {th }}$ bank in year $\mathrm{t}$

$\mathrm{BS}_{\mathrm{it}} \quad=$ Bank size (natural logarithm of total assets) of $\mathrm{i}^{\text {th }}$ bank in year $\mathrm{t}$

$\mathrm{B}_{0} \quad=$ The intercept (constant)

$\beta_{1,} \beta_{2,} \beta_{3,} \beta_{4}, \beta_{5}=$ The slope which represents the degree with which bank performancechanges as the independent variable changes by one unit variable.

$\mathrm{e}_{\mathrm{it}} \quad=$ error component

The selected study variables, their definition, basis of measurement and priori expectedsign have been depicted in Table.

\section{Table 1: Variables definition, measurement and expected sign}

Expected sign is a statistical technique which shows the relationship between two variables. The positive expected sign means that one variable increase, the other variable will also increase while negative expected sign means that when one variable increase, the other variable will be decrease.

\begin{tabular}{|c|c|c|c|c|}
\hline No. & $\begin{array}{c}\text { Abbreviation } \\
\text { variables }\end{array}$ & Description & Measurement & $\begin{array}{c}\text { Expected } \\
\text { sign }\end{array}$ \\
\hline 1 & ROA & Return on Assets & $\begin{array}{l}\text { ROA is the ratio between net profits } \\
\text { to Total } \\
\text { Assets of the bank. }\end{array}$ & NA \\
\hline 2 & NPLR & Non-performing loan ratio & $\begin{array}{l}\text { Non-performing loan/Gross loans and } \\
\text { advances }\end{array}$ & - \\
\hline 3 & CAR & Capital adequacy ratio & Capital/ Risk weighted Assets. & + \\
\hline 4 & CDR & Credit to Deposit ratio & $\begin{array}{l}\text { Credit to Deposit Ratio is a ratio between } \\
\text { total loans and total deposits. This ratio } \\
\text { measures the ability of the management } \\
\text { to use the assets in offering loans } \\
\text { which ultimately creates high } \\
\text { profitability. }\end{array}$ & - \\
\hline 5 & MQR & Management Quality Ratio & $\begin{array}{l}\text { Total Operating Income to Total } \\
\text { Assets as a measure of management } \\
\text { quality. }\end{array}$ & + \\
\hline 6 & BS & Bank size & Natural logarithm of total assets & + \\
\hline
\end{tabular}

\section{Result and Discussion}

\section{Descriptive Statistics}

The summary of the descriptive statistics for all variables used in the study is presented in Table 1. Thetable reports single bank financial performance indicator is return on assets (ROA) and five credit riskindicators which are the capital adequacy ratio (CAR), non-performing loan ratio (NPLR), management quality as measured by total operating income to total assets (MQR), credit to deposit ratio (CDR) and bank size(BS).. The result shows that the average value of the bank performance

ROA is 1.66 percent indicating that during the period 2015 to 2020 , on average, the total assets of sample commercial banks in Nepal generate 1.66 percent return. The standard deviation of the ROAis 0.497 percent, which shows the substantial variation in returns of the banks. The minimum capital adequacy ratio is 10.96 percent 
Table 2: Summary Statistics

\begin{tabular}{r|rrrrr} 
Variable & Obs & Mean & Std. Dev. & Min & Max \\
\hline ROA & 85 & 1.666471 & .4976964 & .69 & 2.82 \\
NPL & 85 & 1.205765 & .985918 & .06 & 4.6 \\
CDR & 85 & 72.72074 & 11.77879 & .7331 & 78.72 \\
CAR & 85 & 14.56059 & 2.702498 & 10.96 & 23.68 \\
MQR & 85 & 4.129647 & .7933945 & 1.84 & 6.64 \\
\hline Size & 85 & 10.98237 & .2257128 & 9.994759 & 11.43788 \\
& & & & & \\
\hline
\end{tabular}

Sources: Annual Report of Sample Banks and Results are drawn from Stata.

Table 2 shows that the number of observations per each variable is equal. This may be explained by the balanced nature of the panel data used in the analysis. Table 2 additionally shows that on average the overall mean return on assets, non- performing loan ratio, credit to deposit ratio, capital adequacy ratio, management quality ratio and bank size were $1.666,1.205,72.720,14.560$ and 4.129 percent respectively. Therefore, over the period the banks were positively profitable, adequately capitalized and experienced some relatively high levels of deterioration in asset quality during the study period.

\section{Correlation Analysis}

The correlation matrix of the variables presented Table 3 reveals that all correlations coefficients among the independent variables are less than 0.7 , implying the absence of multicollinearity. Thus, there is no evidence of presence of multicollinearity among the independent variables.

\section{Table 3: Correlation Coefficient Matrix}

\begin{tabular}{r|rrrrr} 
& NPL & CDR & CAR & MQR & Size \\
\hline NPL & 1.0000 & & & & \\
CDR & -0.0916 & 1.0000 & & & \\
CAR & 0.2825 & -0.0911 & 1.0000 & & \\
MQR & 0.2746 & -0.0651 & 0.3830 & 1.0000 & \\
Size & -0.1300 & -0.2137 & -0.0366 & 0.0526 & 1.0000 \\
\hline
\end{tabular}

Source: Result drawn from Stata.

\section{Regression Analysis}

Table 4 indicates that the value of R-square was 0.4976 , which means that 49.76 percent of the total variation in the value of ROA was due to the effect of the independent variables. The adjusted R-squarewas 0.4658 which shows that on an adjusted basis, the independent variables were collectively 46.58 percent related to the dependent variable ROA. 


\section{Table 4: Regression Result of Credit Risk Management on Performance.}

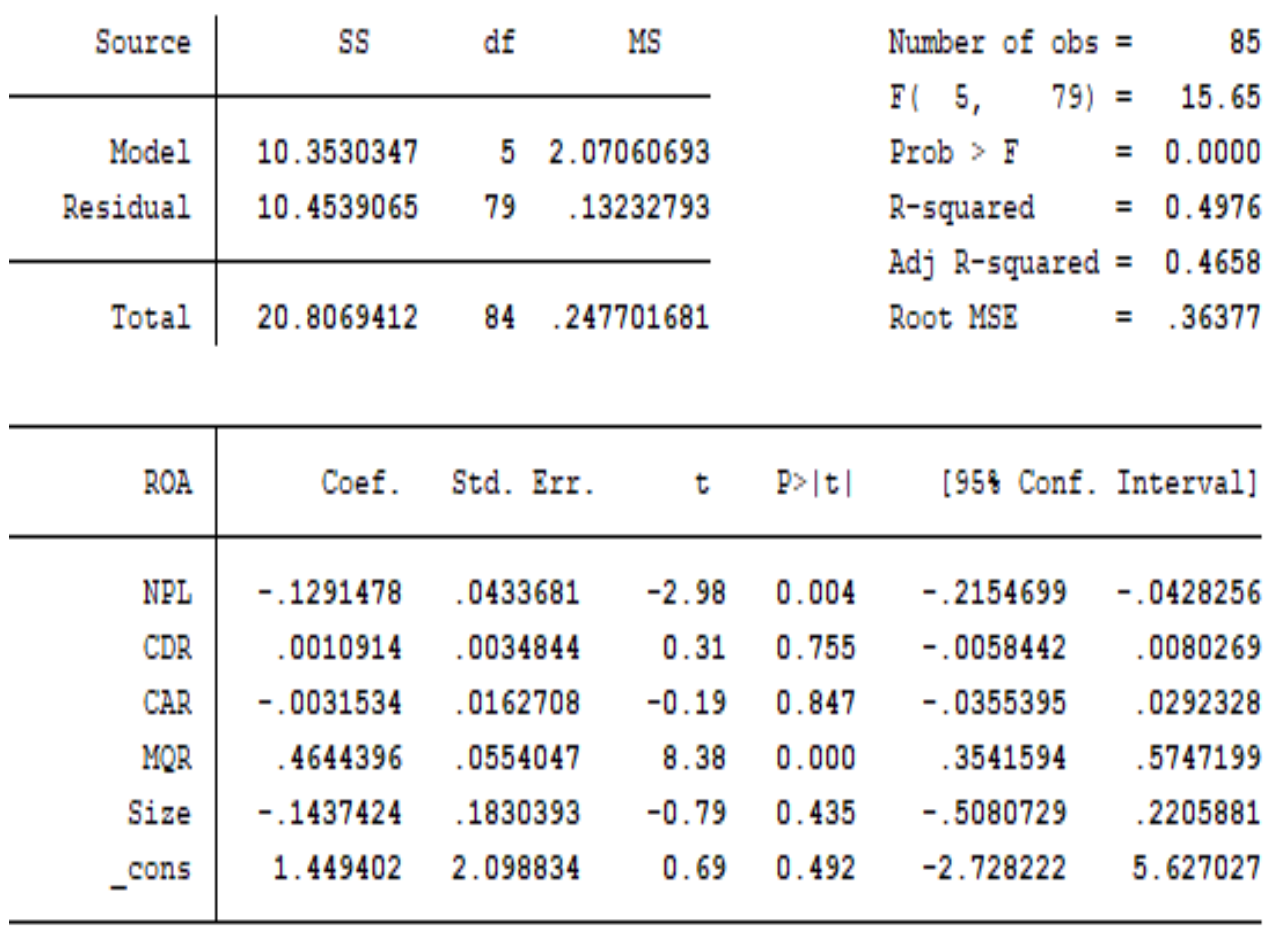

Source: Annual report of sample bank and results are drawn from Strata.

As expected, there is a strong negative association between non-performing loans and financial performance of commercial banks but, it has significant relationship with ROA. The result is contrary to the findings of Alshatti (2015) who found the positive effect of non-performing /gross loans ratio on the financial performance of banks. The result reveals that as CDR commercial bank increases, the performance of the bank will also increase. However, there is positive and no significant correlation between return on assets. The result indicates that capital adequacy ratio is negative and insignificant. The sign of the coefficient is as unusual because theoretically capital adequacy ratio was expected to have a positive relationship with a performance of the commercial banks. However, the finding of this study supportsthe hypothesis that capital adequacy ratio has a significant effect on financial performance of the commercial banks in Nepal. The result is contrary to the findings of Bhattarai (2016).

The result indicates that, management quality ratio has positive and statistically significant. TheFinancial performance of the banks (ROA) is significantly positively correlated with management quality ratio which implies that as the value of total operating income increases, the performance of banks will also increase. Finding of this study has supported the hypothesis that management efficiency ratio has a significant effect on financialperformance of the commercial banks in Nepal. There is negative and no significant relationship between bank size an financial performance (ROA) which indicates that the relationship is weak between bank size and financial performance of the commercial banks. The result is contrary to the findings of Bhattarai (2016)

Hence, Regression analysis is valid as it has satisfied all assumptions. all the assumptions are tested to check the validation of the regression analysis which is shown in figure below.

Linear regression assumes that there is liitle or no multicollinearity in the data. Multicollineraity occurs when the independent variables are too highly correlated with each other. Researcher has test multicollinearity by Variance Inflation Factor (VIF) The variance inflation factor (VIF) value describe the multicollinearity of the statistics; and a VIF of 10 or more show the problem of multicollinearity The value of VIF value shown in table below indicate that there isno problem of multicollinearity in the statistics of the data under study. 


\section{Table: 5 Test For Multicollinearity}

\begin{tabular}{|c|c|c|}
\hline Variable & VIF & $1 / \mathrm{VIF}$ \\
\hline CAR & 1.23 & 0.814753 \\
\hline MQR & 1.23 & 0.815269 \\
\hline NPL & 1.16 & 0.861686 \\
\hline Size & 1.08 & 0.922935 \\
\hline$C D R$ & 1.07 & 0.935212 \\
\hline Mean VIF & 1.15 & \\
\hline
\end{tabular}

In statistics, the Breusch-Pagan test, developed in 1979 by Trevor Breusch and Adrian Pagan, is used to test for heteroskedasticity in a linear regression model. It was independently suggested with some extension by R. Dennis Cook and Sanford Weisberg in 1983 (Cook-Weisberg test). Derived from the Lagrange multiplier test principle, it tests whether the variance of the errors from a regression is dependent on the values of the independent variables. Hence, There exist no problem of heteroskedasticity.

\section{Table 6: Test for Heteroskedasticity}

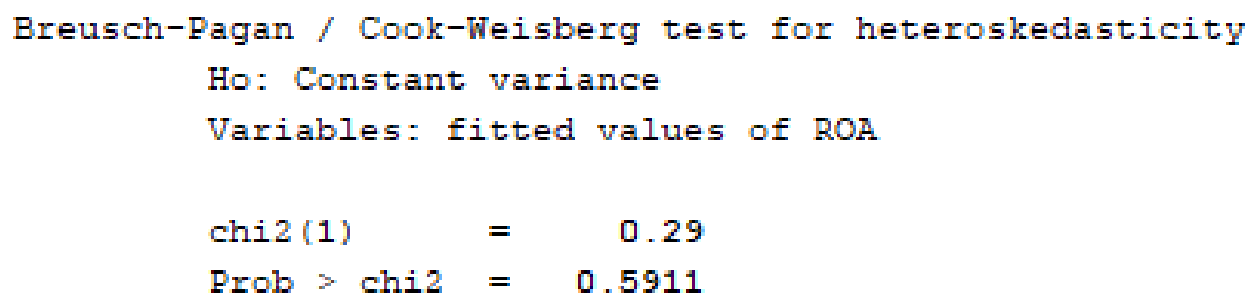

Multiple regression needs the relationship between the independent and dependent variables to be linear. It is also important to check for outliers. It is important to check for outliers since multiple linear regression is sensitive to outlier effects. The linearity assumption can best be tested sensitive to outlier's effects. The linearity assumption can best be tested with scatter plots.

Linear regression analysis requires all variables to be multivariate normal. Normality test are used to determine if a data set is well-modeled by a normal distribution and to compute how likely it is for a random variable underlying the data set to be normally distributed. For the normality test, Kernel density test is done to check whether data are normal or not and it shows almost all data are normally distributed.

Linear regression analysis requires that there is little or no autocorrelation in the data. Autocorrelation occurs when the residuals are not independent from each other. Study shows there is no autocorrelation while, a scatterplot allows to check for auto correlated.

\section{Conclusion.}

Credit risk management should be at the center of banks operations in order to maintain financial stability. Credit risk management includes the system process and control which a company has in place to ensure the efficient collection of customer payment and the risk of no-payment. To achieve the goal of owners' wealth maximization, banks should manage their assets, liabilities and capital efficiently. In doing this, credit policy should set out the bank's lending philosophy, specific proceduresand means of monitoring the lending activity. 
The main purpose of this study is to investigate the impact of credit risk on the financial performance of commercial banks in Nepal. The financial performance in terms of return on assets selected as dependent variables. The capital adequacy ratio, non-performing loan asset, management efficiency, liquidity and bank size are taken as independent variables. The balance panel data of seventeen commercial banks with 85 observations for the period of 2015 to 2020 have been used for the analysis. The regression results indicate the existence of the relationship between the dependent and independent variables hence has the ability to predict the influence of credit risks on the profitability of the commercial banks in Nepal. The model is well fitted with 49.76 percent ability to influence the financial performance of the commercial banks in Nepal. The regression model revealed that NPLR has negativeand statistically significant impact on financial performance of the commercial banks in Nepal. The result in this study therefore, suggested the need for strong credit risk and loan service process management must be adopted to keep the level of NPL as low as possible which will enable to maintain the high performance (profitability) of commercialbanks in Nepal.

Capital adequacy ratio and bank size have negative and statistically no significant impact on the financial performance of the commercial banks in Nepal. Credit to deposit ratio has positive but no significant relationship with the financial performance (ROA). The study concluded that the MQR has positive and significant relationship with the financial performance (ROA) of the commercial banks in Nepal. The study also suggests that the further study can be done on the impact of credit risk management by the use of CAMELS indicators on the financial performance of other bank and financial institutions like micro finance institutions, development banks, finance companies etc. The study recommends that it is fundamental for Nepalese commercial banks to practice scientific credit risk management, Nepal should enhance their capacity in credit analysis and loan administration while the regulatory authority should pay more attention to banks compliance to relevant directives and prevailing rules and regulations.

Banks need to place and devise strategies that will not only limit the banks exposition to credit risk but will develop performance and competitiveness of the banks, and banks should establish a proper credit risk management strategies by conducting sound credit evaluation before granting loans to customers, improve their efficacy in credit analysis and loan management to secure as much as possible their assets, and minimize the high incidence of non-performing loans and their negative effects on financial performance.

It is recommended that bank's credit- granting activities conform to the established strategy that written procedures should be developed and implemented, and that loan approval and review responsibilities are clearly and properly assigned. Senior management must also ensure that there is a periodic independent internal assessment of the bank credit-granting and management functions.

\section{REFERENCES}

Abiola, I. and A. S. Olausi. 2014. "The Impact of Credit Risk Management on the Commercial Banks Performance in Nigeria." International Journal of Management and Sustainability, 3(5): 295-306.

Ahsan, M.K (2016). Measuring financial performance based on CAMEL: A study on selected Islamicbanks in Bangladesh. Asian Business Review, 6(1), 47-54.

Alshatti, A. S. 2015. "The effect of credit risk management on financial performance of the Jordanian commercial banks." Investment Management and Financial Innovations, 12(1): 338-345.

Baral, K.J (2005). Health check-up of commercial banks in the framework of CAMEL: A case studyof joint venture banks in Nepal. The Journal of Nepalese Business Studies, 2(1), 41-55.

Bhattarai, Y.R. (2016). The effect of credit risk on the performance of Nepalese commercial banks. NRB Economic Review, 28(1),41-62

Das, A. and Ghosh, S. (2007). Determinants of credit risk in Indian state owned banks: An empirical investigation. MPRA Paper, 1-21.

Ezike, J.E. and M. D. Oke. 2013. "Capital adequacy standards, Basel accord and bank performance: the Nigerian experience (A case study of selected banks in Nigeria)." Asian Econ. Finance Rev., 3(2): 146-159. 
Fredrick, O (2012). The impact of credit risk management on the financial performance of commercialbanks in Kenya. African Management Review, 3(1), 22-37.

Gadzo, S.G.,Kportorgbi, H.K. and Gatsi, J.G. (2019). Credit risk and operational risk on financial performance of universal banks in Ghana: A partial least squared structural equation model (PLS SEM) approach. Cogent Economics \& Finance, 7, 1-16, 7:1589406. https://doi.org/10.1080/23322039.2019.1589406

Ibrahim, M.(2014). A comparative performance of two banks in United Arab Emirates. Research Journal of Finance and Accounting, 5(21).

Jha, S, and Hui, X.(2012). A comparison of financial performance of commercial banks: A case studyof Nepal. African Journal of Business management, 6(25),7601-7611.

Kattel, I.K(2016). Evaluating the credit risk measurement practices of commercial banks in Nepal. Journal of Business and Management, 18(3), 132-137.

Kurawa, J.M. and S. Garba. 2014. "An Evaluation of the Effect of Credit Risk Management (CRM) on the Profitability of Nigerian Banks." Journal of Modern Accounting and Auditing, 10(1): 104-115. Available at: http://www.academia.edu

Mohiuddin, G.(2014). Use of CAMEL model: A study on the financial performance of selectedcommercial banks in Bangladesh. Universal Journal of Accounting and Finance, 2(5), 51-160.

Muriithi, J.G, Waweru, K.M, Muruti, W.M.(2016). Effect of credit risk on financial performance of commercial banks in Kenya. Journal of Economics and Finance, 7(4), 72-83.

Molyneux, P. and J. Thorton. 1992. "Determinants of European Bank Profitability: A Note." Journal of Banking and Finance, 16(6): 1173-1178.

Naceur, S. B. 2003. The Determinants of the Tunisian Banking Industry Profitability: Panel Evidence, Universite Libre de Tunis Working Papers.

Poudel, R.P.S (2012). The impact of credit risk management on the financial performance of commercial banks in Nepal. International Journal of Arts and Commerce, 1(5), 9-15

Shukla, S.S (2015). Analysing financial strength of public and private sector banks: A CAMEL Approach. Pacific Business Review International, 7(8),44-50.

Smirlock, M. 1985. "Evidence of non-relationship between concentration and profitability inBanking." Journal of Money, Credit and Banking, 17: 69-83.

Ugoani, J. N. N. 2015. "Poor Credit Risk Management and Bank Failures in Nigeria." International Journal of Economics and Business Administration, 1(1): 17-24. Available at http://www.aiscience.org/ journal/ijeba 